\title{
The Resource Potential of the Agro-industrial Complex of the North-Caucasian Federal District as a Factor of Innovative Development of the Macro-region
}

Keywords: Resource potential of the region, agro-industrial complex, agriculture, North Caucasus Federal district, innovative development, state regulation of agriculture.

JEL Codes: Q10, O39.

Paper Type: Research article in Special Issue dedicated to Russian Economy.

Section 7: Economic Development.

\footnotetext{
${ }^{1}$ Ph.D. in Economics, Institute of Socio-economic Research of Dagestan Scientific Center of Russian Academy of Science, Makhachkala, Russian Federation, reklama-ka@ rambler.ru ${ }^{2}$ D.Sc. in Economics, Professor, Chief-researcher of the Institute of Socio-economic Research of Dagestan Scientific Center of Russian Academy of Science, Makhachkala, Russian Federation, sergsvd@ mail.ru

${ }^{3}$ Lecture at the Department of World and Regional Economics of Dagestan State University, hidirova.s@mail.ru

${ }^{4}$ Post-graduate of the Department of Economics and Management in Agriculture of Dagestan State Agrarian University named after M.M. Dzhambulatov.
} 


\section{Introduction}

The implementation of the regional policy aimed at ensuring the economic development of the regions, puts forward as the main direction of sustainable development the effective use of the resource potential, ensuring the process of regional reproduction. Due to the fact that agricultural regions are mainly a group of problematic, as well as the growing demand for the main types of crops in the national and world markets, there is an urgent question of improving the efficiency of the use of the resource potential of regions with a significant agricultural component, which include the regions of the North Caucasus Federal district (NCFD) - (in 2016 the share of GRP agriculture in the GRP of the NCFD amounted to $25 \%$, the area of farmland in the total land area $-70 \%$, the share of the rural population - 50.9\%) (Regions of Russia, 2018).

Often, under the resource potential of agriculture, researchers assume a set of production resources. Some authors (Dokholyan and Umavov, 2011; Yunusova, 2015) considering the resource potential of the agricultural sector of the region, take into account not only the quantitative but also the qualitative side of the resources necessary for the expanded reproduction of the ecological, social and economic system of the region, which determine the limits of the total social product of the agricultural sector. The disadvantage of this approach is that it involves looking at the resource potential in terms of agricultural resource requirements, while the term "capacity" itself implies the possibility, the ability, assuming a certain level of return on the resources used, as well as unrealized reserves. Based on this, a more reasonable approach to the disclosure of the concept of resource potential, assume the definition of it as opportunities limited by the conditions of regional production. It is also necessary to distinguish between the resource and agricultural production potential of the region, as the production involves only the productive part of production, which can produce enterprises, and the resource is a total assessment of the used resources.

\section{Key Trends in the Use of the Resource Potential of Agro-industrial Complex}

The structural elements of the resource potential of the agricultural sector are the natural, labor, material, technical and innovative potential (Dokholyan and Farmanov, 2011). Natural and environmental resources largely determine crop yields, product quality, production costs, especially agricultural activities, territorial specialization. The main quantitative characteristic of the natural potential is the area of agricultural land. The North-Caucasian Federal district has a significant resource base in agriculture. The presence of extensive arable land, good agro-climatic conditions, a significant distance from industrial centers and as a result, high environmental friendliness of products - important pre-emptive factors that enable the region to become one of the leaders in agricultural production in Russia. 
Agricultural lands of NCFD make up $3.5 \%$ of the land in this category of the Russian Federation. The largest share of them in the region accounts for the Stavropol territory - $45 \%$ and the Republic of Dagestan - 32\%. The remaining subjects of the district are to a much lesser extent provided with farmland; the Republic of Ingushetia has the least resource - a little more than $1 \%$.

Table 1. Land distribution of the North-Caucasian Federal District by categories (as of January 1, 2018, thousand hectares) (Regions of Russia, 2018)

\begin{tabular}{|c|c|c|c|c|c|c|c|c|}
\hline & $\begin{array}{l}\text { Agricultura } \\
1 \text { land }\end{array}$ & $\begin{array}{l}\text { Lands of } \\
\text { settlemen } \\
\text { ts }\end{array}$ & $\begin{array}{l}\text { Industrial } \\
\text { lands and } \\
\text { other } \\
\text { special } \\
\text { purpose }\end{array}$ & $\begin{array}{l}\text { Lands of } \\
\text { specially } \\
\text { protected } \\
\text { territories } \\
\text { and } \\
\text { objects }\end{array}$ & $\begin{array}{l}\text { The } \\
\text { lands of } \\
\text { the } \\
\text { forest } \\
\text { Fund }\end{array}$ & $\begin{array}{l}\text { Water } \\
\text { Fund } \\
\text { lands }\end{array}$ & $\begin{array}{l}\text { Reser } \\
\text { ve } \\
\text { lands }\end{array}$ & $\begin{array}{l}\text { Total land } \\
\text { in } \\
\text { administrat } \\
\text { ive borders }\end{array}$ \\
\hline Russia & 383227,7 & 20453 & 17454,9 & 47694,2 & 1126288 & 28069,9 & $\beta 9330$ & 1712519,1 \\
\hline \begin{tabular}{|l|} 
North- \\
Caucasian \\
Federal \\
District \\
\end{tabular} & 13537,9 & 709,3 & 182,3 & 307,6 & 1744 & 107,3 & 455,5 & 17043,9 \\
\hline $\begin{array}{l}\text { Republic of } \\
\text { Dagestan }\end{array}$ & 4344,5 & 160,5 & 43,3 & 28,7 & 421,6 & 26,6 & 1,8 & 5027 \\
\hline $\begin{array}{l}\text { Republic } \\
\text { of } \\
\text { Ingushetia }\end{array}$ & 150,9 & 39,2 & 5,7 & p,2 & 32,7 & 0,6 & 32,5 & 362,8 \\
\hline \begin{tabular}{|l|} 
Kabardino- \\
Balkar \\
Republic \\
\end{tabular} & 711,5 & 57,6 & 11,3 & 54,8 & 260,5 & 2,8 & 148,5 & 1247 \\
\hline $\begin{array}{l}\text { Karachay- } \\
\text { Cherkess } \\
\text { Republic }\end{array}$ & $\beta 16,8$ & 38,7 & 15,1 & 125,4 & 390,7 & 10,2 & $\beta 0,8$ & 1427,7 \\
\hline \begin{tabular}{|l|} 
Republic of \\
North \\
Ossetia \\
Alania
\end{tabular} & 418,7 & 59,7 & 16,7 & 88 & 177,4 & 2,5 & 25,7 & 798,7 \\
\hline $\begin{array}{l}\text { Chechen } \\
\text { Republic }\end{array}$ & 993,1 & 104 & 33,9 & p & 296,6 & $\beta, 7$ & 128,4 & 1564,7 \\
\hline $\begin{array}{l}\text { Stavropol } \\
\text { Region }\end{array}$ & 5102,4 & 249,6 & 55,3 & p,5 & 14,5 & 55,9 & $\beta 7,8$ & 5616 \\
\hline
\end{tabular}

The distribution of the land fund by land categories by subjects of the NCFD showed that the predominance of agricultural land is observed in the Stavropol territory - $92 \%$, in the Republic of Dagestan - 86\%, to a lesser extent - in the Chechen Republic 63\%, Karachay-Cherkessia Republic - 57\%, Kabardino-Balkar Republic-57\%, in the Republic of North Ossetia - Alania - 52\%. The lowest share 
of agricultural land accounts for the Ingush Republic -41\% (Baliyants et al., 2018; Regions of Russia, 2018). In general, $67 \%$ of the lands subject to irrigation are not in good condition: in satisfactory - $27 \%$ and in unsatisfactory condition - $40 \%$ of the lands. Of the subjects, the largest number of lands in poor condition is the Republic of Dagestan - 53\% of all reclaimed land in the Chechen Republic - 76\%, the Republic of Ingushetia - 78\% (Baliyants et al., 2018; Regions of Russia, 2018).

Table 2. Agricultural products of the North-Caucasian Federal District (Regions of Russia, 2018) (in farms of all categories; in current prices; million rubles)

\begin{tabular}{|l|l|l|l|l|l|l|l|l|l|}
\hline & 2005 & 2010 & 2011 & 2012 & 2013 & 2014 & 2015 & 2016 & $\begin{array}{l}2016 \\
\text { to } \\
2015 \\
\%\end{array}$ \\
\hline $\begin{array}{l}\text { North- } \\
\text { Caucasian } \\
\text { Federal } \\
\text { Federal } \\
\text { District }\end{array}$ & 104073 & 205337 & 246424 & 258231 & 299940 & 341517 & 408625 & 450671 & 110 \\
\hline $\begin{array}{l}\text { Republic } \\
\text { of } \\
\text { Dagestan }\end{array}$ & 25197 & 48701 & 57182 & 66054 & 76814 & 87915 & 99541 & 113363 & 114 \\
\hline $\begin{array}{l}\text { Republic } \\
\text { of } \\
\text { Ingushetia }\end{array}$ & 1958 & 3218 & 4476 & 3903 & 4640 & 5464 & 6691 & 8590 & 128 \\
\hline $\begin{array}{l}\text { Kabardino- } \\
\text { Balkar } \\
\text { Republic }\end{array}$ & 13581 & 24136 & 27738 & 30286 & 32699 & 34330 & 38992 & 43697 & 112 \\
\hline $\begin{array}{l}\text { Karachay- } \\
\text { Cherkess } \\
\text { Republic }\end{array}$ & 6633 & 16225 & 19197 & 19722 & 22430 & 23837 & 30487 & 32164 & 106 \\
\hline $\begin{array}{l}\text { Republic } \\
\text { of North } \\
\text { Ossetia } \\
\text { Alania }\end{array}$ & 7639 & 17801 & 21464 & 23448 & 25877 & 25719 & 26653 & 24484 & 92 \\
\hline $\begin{array}{l}\text { Chechen } \\
\text { Republic }\end{array}$ & 4552 & 10993 & 12897 & 13605 & 14706 & 15250 & 17704 & 21291 & 120 \\
\hline $\begin{array}{l}\text { Stavropol } \\
\text { Region }\end{array}$ & 44513 & 84263 & 103470 & 101214 & 122775 & 149001 & 188556 & 207082 & 110 \\
\hline
\end{tabular}

Over the past 10 years, the North-Caucasian Federal District in general increases the production of agricultural products, but the rate of growth in this period slowed significantly and fell from $19 \%$ to $10 \%$. Considering the region in the context of the subjects, it should be noted that the growth rates increased only in one of them - the Chechen Republic (4\%), the rest showed a steady decline (Table 2). As can be seen from Table 3, the gross regional product of the NCFD tends to grow, as does the gross regional agricultural product of the region. The share of GRP in agriculture in the total GRP increased by $4 \%$ and accounted for a quarter of it. 
Table 3. The share of gross regional product in rural agriculture in the gross regional product (Baliyants, 2018; Regions of Russia, 2018), $m \ln$ RUB.

\begin{tabular}{|c|c|c|c|c|c|c|c|}
\hline & \multicolumn{3}{|l|}{2015} & \multicolumn{4}{|l|}{2016} \\
\hline & $\begin{array}{l}\text { Gross } \\
\text { regional } \\
\text { product }\end{array}$ & & $\begin{array}{l}\text { the share } \\
\text { of GRP in } \\
\text { agricultur } \\
\text { e GRP, \% }\end{array}$ & GRP & GRP AG & $\begin{array}{l}\text { the share of } \\
\text { GRP in } \\
\text { agriculture } \\
\text { GRP, }\end{array}$ & $\begin{array}{l}\text { Rating among } \\
\text { the regions of } \\
\text { the Russian } \\
\text { Federation }\end{array}$ \\
\hline $\begin{array}{l}\text { North- } \\
\text { Caucasian } \\
\text { Federal } \\
\text { District }\end{array}$ & 1704331 & 408625 & 24 & 1797972 & 450671 & 25 & 5 \\
\hline $\begin{array}{l}\text { Republic } \\
\text { of } \\
\text { Dagestan }\end{array}$ & 559673,1 & 99541 & 18 & 597096,7 & 113363 & 19 & 15 \\
\hline $\begin{array}{l}\text { Republic } \\
\text { of } \\
\text { Ingushetia }\end{array}$ & 54330,4 & 6691 & 12 & 50882,9 & 8590 & 17 & 75 \\
\hline $\begin{array}{l}\text { Kabardino- } \\
\text { Balkar } \\
\text { Republic }\end{array}$ & 125393,1 & 38992 & 31 & 132706,9 & 43697 & 33 & 38 \\
\hline $\begin{array}{l}\text { Karachay- } \\
\text { Cherkess } \\
\text { Republic }\end{array}$ & 67355,2 & 30487 & 45 & 73151,3 & 32164 & 44 & 50 \\
\hline $\begin{array}{l}\text { Republic } \\
\text { of North } \\
\text { Ossetia - } \\
\text { Alania } \\
\end{array}$ & 127543,9 & 26653 & 21 & 125498,3 & 24484 & 20 & 57 \\
\hline $\begin{array}{l}\text { Republic } \\
\text { of } \\
\text { Chechnya }\end{array}$ & 160503,2 & 17704 & 11 & 166711,2 & 21291 & 13 & 64 \\
\hline $\begin{array}{l}\text { Stavropol } \\
\text { Region }\end{array}$ & 609531,9 & 188556 & 31 & 651925 & 207082 & 32 & 5 \\
\hline
\end{tabular}

Production of livestock products increased over the period from 5 to $20 \%$. For the production of milk and eggs, the region retained its values, but in previous years there was a stable growth. For meat production, the leading indicators with a growth trend $(11 \%)$ belong to the Stavropol territory, which is due to the best of the district's land and traditional specialization. The Republic of Dagestan in recent years has significantly increased its position in the production of livestock products and holds the leadership in the production of NCDF milk, wool and honey with a growth trend (respectively 3\%, 6\%, 85\%compared to the previous period) (Dokholyan et al., 2018).

Considering the location of the district, where in most subjects moderately cold winters with a large number of Sunny days and warm temperatures, it is important to develop large-scale production, while maintaining other forms of management farm and private individual enterprises. Personal subsidiary farms occupy a significant place in the economy of agriculture of all the republics of the region, but 
with the emergence of large commodity farms and the emergence of stable jobs and earnings in rural areas, their role in the production of commodity products will decline (Kurbanov et al., 2016).

The contribution of the North-Caucasian Federal District in the production of agricultural products in Dagestan is $17.9 \%$, the proportion of the Karachay-Cherkess Republic $-7,3 \%$, the proportion of the Kabardino-Balkarian Republic is $13.6 \%$. In these subjects, the food and processing industries provide more than $50 \%$ of the food products of the regional food market, are the Central links in the structure of the economy of these republics (Regions of Russia, 2018). In the final top list analyzed the largest agricultural enterprises of the North- Caucasian Federal district, which for the year produced the largest number of products in its segment. The data were based on two main criteria - the volume of production and design capacity and collected based on information from regional ministries (Ministry of agriculture of the Russian Federation, 2018; Ministry of agriculture and food of the Republic of Dagestan, 2018).

Table 4. The security of the agricultural organizations of North-Caucasian Federal district tractors (Bulletins on the State of Agriculture, 2018)

\begin{tabular}{|l|l|l|l|l|}
\hline & \multicolumn{2}{|l|}{$\begin{array}{l}\text { Tractors account for } \\
1000 \text { hectares of arable land, } \\
\text { pieces }\end{array}$} & $\begin{array}{l}\text { Account for arable land on 1 } \\
\text { tractor, ha }\end{array}$ \\
\cline { 2 - 5 } & 2016 & 2017 & 2016 & 2017 \\
\hline Russian Federation & 3,1 & 3,1 & 318 & 327 \\
\hline $\begin{array}{l}\text { North-Caucasian } \\
\text { Federal District }\end{array}$ & 3,7 & 3,6 & 274 & 281 \\
\hline $\begin{array}{l}\text { Republic of } \\
\text { Dagestan }\end{array}$ & 4,4 & 4,2 & 228 & 241 \\
\hline $\begin{array}{l}\text { Republic of } \\
\text { Ingushetia }\end{array}$ & 5,6 & 5,7 & 177 & 174 \\
\hline $\begin{array}{l}\text { Kabardino-Balkar } \\
\text { Republic }\end{array}$ & 3,6 & 3,6 & 275 & 276 \\
\hline $\begin{array}{l}\text { Karachay-Cherkess } \\
\text { Republic }\end{array}$ & 3,4 & 3,3 & 291 & 301 \\
\hline $\begin{array}{l}\text { Republic of North } \\
\text { Ossetia-Alania }\end{array}$ & 2,2 & 2,7 & 459 & 373 \\
\hline $\begin{array}{l}\text { Republic of } \\
\text { Chechnya }\end{array}$ & 3,1 & 3,0 & 324 & 332 \\
\hline Stavropol Region & 3,7 & 3,5 & 273 & 282 \\
\hline
\end{tabular}

The insufficiency of the material and technical component of agriculture in the region is a limiting factor in the formation of its resource potential. From the data of Table 5 it follows that the provision of agricultural organizations with harvesters either has not changed in the last two years or continues to decrease. 
Table 5. The security of the agricultural organizations of the NCFD harvesters (Bulletins on the State of Agriculture, 2018)

\begin{tabular}{|c|c|c|c|c|c|c|c|c|}
\hline & \multicolumn{8}{|c|}{$\begin{array}{l}\text { Account for combines per } 1000 \text { hectares of crops (planting) of the } \\
\text { respective crops, pieces }\end{array}$} \\
\hline & \multicolumn{2}{|c|}{$\begin{array}{l}\text { Combine } \\
\text { harvesters }\end{array}$} & \multicolumn{2}{|c|}{ corn harvesters } & \multicolumn{2}{|c|}{ potato harveste } & \multicolumn{2}{|c|}{$\begin{array}{l}\text { beet harvesters } \\
\text { (without toppers) }\end{array}$} \\
\hline & 2016 & 2017 & 2016 & 2017 & 2016 & 2017 & 2016 & 2017 \\
\hline $\begin{array}{l}\text { Russian } \\
\text { Federation }\end{array}$ & 2 & 2 & 0 & 0 & 15 & 17 & 2 & 2 \\
\hline $\begin{array}{l}\text { North-Caucasian } \\
\text { Federal District }\end{array}$ & 3 & 3 & 0 & 0 & 9 & 10 & 3 & 3 \\
\hline $\begin{array}{l}\text { Republic of } \\
\text { Dagestan }\end{array}$ & 6 & 6 & 25 & 21 & & & & \\
\hline $\begin{array}{l}\text { Republic of } \\
\text { Ingushetia }\end{array}$ & 5 & 7 & 2 & 1 & & & & \\
\hline $\begin{array}{l}\text { Kabardino- } \\
\text { Balkar Republic }\end{array}$ & 2 & 2 & 1 & 2 & 9 & 10 & & \\
\hline $\begin{array}{l}\text { Karachay- } \\
\text { Cherkess } \\
\text { Republica } \\
\end{array}$ & 2 & 4 & & 0 & 5 & 2 & 13 & 3 \\
\hline $\begin{array}{l}\text { Republic of } \\
\text { North Ossetia - } \\
\text { Alania }\end{array}$ & 2 & 3 & 0 & 0 & 2 & 5 & & \\
\hline $\begin{array}{l}\text { Republic of } \\
\text { Chechnya }\end{array}$ & 3 & 2 & 0 & 0 & 8 & & 2 & 1 \\
\hline Stavropol Region & 3 & 3 & 0 & 0 & 14 & 18 & 3 & 3 \\
\hline
\end{tabular}

Agricultural production is based not only on natural and climatic factors. Man takes a constant active part in this process, i.e. it is human labor that is the main source and condition of agricultural production. The labor potential of agriculture in the region is the number of people of working age who have the ability and opportunity to work in this area. Energy security plays an important role (Table 6).

Table 6. Energy supply of agricultural organizations (energy capacity per 100 hectares of acreage), HP (horsepower) (Bulletin on the State of Agriculture, 2018)

\begin{tabular}{|l|l|l|l|l|l|l|l|}
\hline & 2012 & 2013 & 2014 & 2015 & 2016 & 2017 & $\begin{array}{l}2017 \text { as \% } \\
\text { of 2016 }\end{array}$ \\
\hline $\begin{array}{l}\text { North-Caucasian } \\
\text { Federal District }\end{array}$ & 254 & 240 & 235 & 223 & 212 & 206 & 97,3 \\
\hline $\begin{array}{l}\text { Republic of } \\
\text { Dagestan }\end{array}$ & 797 & 585 & 494 & 435 & 423 & 434 & 102,5 \\
\hline $\begin{array}{l}\text { Republic of } \\
\text { Ingushetia }\end{array}$ & 177 & 179 & 195 & 192 & 181 & 230 & 127,2 \\
\hline $\begin{array}{l}\text { Kabardino- } \\
\text { Balkar Republic }\end{array}$ & 291 & 214 & 259 & 272 & 283 & 268 & 94,8 \\
\hline
\end{tabular}




\begin{tabular}{|l|l|l|l|l|l|l|l|}
$\begin{array}{l}\text { Karachay- } \\
\text { Cherkess } \\
\text { Republic }\end{array}$ & 282 & 256 & 280 & 240 & 277 & 288 & 104,0 \\
\hline $\begin{array}{l}\text { Republic of } \\
\text { North Ossetia - } \\
\text { Alania }\end{array}$ & 153 & 128 & 120 & 125 & 119 & 102 & 86,1 \\
\hline $\begin{array}{l}\text { Republic of } \\
\text { Chechnya }\end{array}$ & 210 & 198 & 121 & 111 & 120 & 105 & 87,2 \\
\hline Stavropol Region & 244 & 237 & 236 & 224 & 210 & 206 & 98,2 \\
\hline
\end{tabular}

And although the rural population in the NCFD prevails over the urban one, the scope of activities of the region's residents is very different. One of the factors of this phenomenon is the fact that wages in the agricultural sectors do not perform their functions - reproductive and motivational. This situation displaces workers from this sphere in more profitable (financial services, trade, public service, transport, communications), which inevitably leads to a weakening of the labor resource potential of the agricultural sphere (Bulletin «North Caucasus» 2015).

The problems of demography, underdevelopment of rural areas, the weakening of the country's economic development, reforms in education - all this contributed to the strengthening of the problem of staffing agricultural producers. Based on the Russian statistics as a whole (Yarkova, 2015; Average salary in the NorthCaucasians Federal District, 2018), we can say that over the past 23 years the dynamics of the number of workers has developed in a far unfavorable way - the problem of aging personnel and low level of their professionalism.

Studies show that in the crop sector about half of the employed (44.9\%) have primary vocational education, secondary vocational education have $21.5 \%$ of the employed. In the livestock sector, the number of workers with primary vocational education and without vocational training is almost equal and amounts to slightly more than $30 \%$ each (32.9 and 33.3\%, respectively). Agricultural producers are facing severe shortage of staff.

\section{Conclusion}

The analysis made it possible to conclude that in the regions of the North-Caucasian Federal District there is almost a full range of resources necessary for the effective operation of the agricultural economy. There are all prerequisites for the effective functioning of grain products, fruits and vegetables, grape-wine, meat, dairy, fatand-oil production. The creation of a favorable economic climate for agricultural producers is not a temporary norm associated with the imposition of sanctions, but a clear strategy of the state. State support should consist in providing agricultural producers with the necessary amount of funds for the implementation of the program, a clear coordination of actions for the production of food, the organization 
of guaranteed sales for agricultural producers in full, the organization of storage of purchased products and the supply of its consumers all year round.

\section{References:}

Average Salary in the North-Caucasian Federal District in 2005-2016. 2018. Electronic resource. https://www.auditit.ru/inform/zarplata/index_old.php?id_region=685(accessed 15.01.2019).

Baliyants, K.M. 2018. Directions of Development of Food Subcomplexes of Agro-industrial Complexes of North-Caucasian Federal District in Conditions of Import Substitution. Regional Problems of Economic Transformation, 12.

Baliyants, K.M., Dokholyan, S.V., Eminova, E.M., Ramazanova, S.C. 2018. The Resource Potential of the Region as the Factor of Formation of the Grocery Subcomplexes in Agro-industrial Complexes of NCFD of the North-Caucasian Federal district. Economics and Management: Problems, Solutions, 9(5).

Bulletin of The North Caucasus. 2015. Dagestan Research Institute of Agriculture named after F.G. Kisriev. Innovative project, http://www.severniykavkaz.ru/articles/ brendysevernogo-kavkaza/2015/\#!/2414.

Bulletins on the State of Agriculture. 2018. Electronic resource, http://www.gks.ru/wps/wcm/connect/ rosstat_main/rosstat/ru/statistics/publications/catalog/doc_1265196018516.

Dokholyan, S.V., Balents, K.M., Eminova, E.M., Jambulatov, A.Z. 2018. Improving the Efficiency of the Resource Potential of the Agro-industrial Complex of the NorthCaucasian Federal District in Solving the Problems of Import Substitution. Economy of Sustainable Development, 4.

Dokholyan, S.V., Farmanov, R.F. 2011. The Rational Use of Production Resources at Agricultural Enterprises. Monograph, Makhachkala, Publishing House "Nauka plus", 168.

Dokholyan, S.V., Umavov, Y.D. 2011. Development of the Resource Potential of Agroindustrial Complex in the System of Regional Reproduction. Regional Problems of Economic Transformation, 4(30), 135-159.

Kurbanov, K.K., Dzhabrailov, R.A., Mahmudov, M.K. 2016. The Use of the Resource Potential of the Regional Agro-industrial Complex in Solving the Problems of Import Substitution. Regional Problems of Economic Transformation, 9(71).

Region of Russia. Socio-economic Indicators. 2018. Electronic resource, http://www.gks.ru/bgd/regl/b16_14p/Main.htm 2018.

The website of the Ministry of Agriculture of the Russian Federation. 2018. Reference on the measures and the directions of the state support of agriculture of the Russian Federation. http://gp.specagro.ru/region/3630/ 2/11/10/2018.

Website of the Ministry of Agriculture and Food of the Republic of Dagestan. 2018. Electronic resource, http://mcxrd.ru/rastenievodstvo.

Yarkova, T.M. 2015. The State of Staffing of Agriculture in Russia. The Perm Agrarian Journal, 4 (12).

Yunusova, P.S. 2013. Innovative Development of Agribusiness as a Tool for Mobilizing the Resource Potential. Regional problems of Economic Transformation, 3(37). 